\title{
A COMPARISON OF THE EFFECTS OF TWO HAEMODILUENTS \\ ON MONOVALENT AND DIVALENT CATIONS IN CHILDREN \\ UNDERGOING CARDIOPULMONARY BYPASS \\ AND OPEN-HEART SURGERY
}

\author{
N. Abrahams, M.B., B.S., F.F.A.R.C.S.(ENG.), A. E. Johnston, M.D., C.M., F.R.C.P.(C), \\ J. TAYLOR, B.SC., H.I.A. NISBET, M.B., CH.B., F.F.A.R.C.S., \\ AND I.C. RADDE, M.D., PH.D., F.R.C.P. (C)
}

\section{INTRODUCTION}

The MATERIAL PResented in this paper is part of an on-going project to study biochemical changes in children undergoing cardiopulmonary bypass (CPB) with haemodilution for open-heart surgery. In previous communications we showed that the concentration of ionic calcium in the haemodiluted pump priming fluid can influence the levels of both monovalent and divalent cations in the plasma. ${ }^{1,2}$ With nearly normal calcium ion activity in the priming solution, plasma electrolyte levels during and after the operation were more frequently at or near normal. However, intra-operative hyponatraemia and post-operative hypokalaemia still occurred and hypomagnesaemia was also observed.

In an attempt to minimize these changes, we have since tried using as the haemodiluent one of the commercial multiple electrolyte solutions containing physiological concentrations of ions: Plasma-lyte ${ }^{\circledR *}$ was chosen because it contains magnesium. To the Plasma-lyte we added dextrose to make a 1 per cent solution, thus maintaining osmolality and blood sugar at acceptable levels. We compared the effects of this solution as diluent with those of the 5 per cent dextrose in 0.2 per cent $\mathrm{NaCl}$ previously used, and also observed differences in the pattern of electrolyte changes during and after cardiopulmonary bypass between patients in whom the bypass period was longer than 50 minutes and those in whom it was less than 30 minutes.

\section{Patients and Methods}

Sixteen patients who were to undergo open-heart operations were assigned to three groups, as shown in Table I. This table also includes details of age, weight, diagnosis, operative procedure, and length of pump run.

From the Departments of Anaesthesia and Paediatric Research, The Research Institute, The Hospital for Sick Children, Toronto, Ontario, and the University of Toronto.

Portions of data in this paper were presented at the Canadian Anaesthetists' Society Meeting, Halifax, June, 1972.

Requests for reprints: Dr. A.E. Johnston, Department of Anaesthesia, The Hospital for Sick Children, 555 University Avenue, Toronto 101, Ontario.

* Plasma-lyte 148 in water: $\mathrm{Na}^{+} 140 \mathrm{mEq} / \mathrm{L} ; \mathrm{K}^{+} 5 \mathrm{mEq} / \mathrm{L} ; \mathrm{Cl}^{-} 98 \mathrm{mEq} / \mathrm{L} ; \mathrm{Mg}^{++} 3 \mathrm{mEq} / \mathrm{L}$; bicarbonate as acetate $27 \mathrm{mEq} / \mathrm{L}$ and as gluconate $23 \mathrm{mEq} / \mathrm{L}$. Travenol Laboratories Inc., Morton Grove, Illinois 60053, U.S.A. 
Group I - consisted of five patients undergoing total correction of tetralogy of Fallot, in whom the period of bypass exceeded 50 minutes (long-pump-run cases) and the haemodiluent was Plasma-lyte with dextrose added to make a 1 per cent solution.

Group $I I$ - consisted of five patients undergoing total correction of tetralogy of Fallot. All were long-pump-run casès $(>50 \mathrm{~min}$ ) but the haemodiluent was 5 per cent dextrose in 0.2 per cent $\mathrm{NaCl}$.

Group III - consisted of six patients undergoing suture closure of an atrial septal defect (ASD), in whom the period of bypass was 30 minutes or less ( short-pumprun cases) and the diluent was Plasma-lyte with dextrose added to make a 1 per cent solution.

Thus, Groups I and II were similar except for the diluent used, and Groups I and III were similar except for the duration of bypass.

All operations were performed under normothermic conditions and the haemodilution, bypass procedure, and anaesthetic techniques were the same in all patients and similar to those used in our previously reported cases. ${ }^{1,2}$

The Temptrol ${ }^{\circledR}$ disposable bubble oxygenator* was employed. The volumes of the diluting fluid and blood to be added were calculated to produce a standardized 30 per cent overall dilution of the combined priming volume plus patient's estimated blood volume ( $\mathrm{EBV})$, that is:

$$
\frac{\text { Total volume of diluents }}{\text { EBV }+ \text { total priming volume }} \times 100=30 \text { per cent. }
$$

The total volume of diluents was considered to be the combined volume of diluting fluid plus the acid-citrate-dextrose (ACD) solution (USP formula A) and the added calcium chloride, heparin, and THAM (trishydroxyaminomethane). The volume of the priming solution was usually about one third greater than the patient's EBV (Table I). We checked the consistency of the degree of haemodilution by noting the haematocrit levels during early bypass.

Blood samples were taken from an indwelling arterial catheter at the following times: (1) at induction of anaesthesia; (2) during operation prior to bypass; (3) during bypass - three samples (early, mid- and late bypass); (4) after bypass during chest closure; (5) post-operatively, every four hours during the first 24 hours, and every eight hours during the second post-operative day.

Urine was collected from an indwelling catheter during the operation and for 48 hours post-operatively; at 4-hour intervals during the first post-operative day and at 8-hour intervals during the second post-operative day.

The specimens were analyzed as follows: arterial $\mathrm{pH}, \mathrm{PcO}_{2}$, and $\mathrm{Po}_{2}$ were measured immediately after the blood was drawn, using radiometer microelectrodes and a PHM $27 \mathrm{pH}$ meter with gas monitor. The haematocrit was measured on blood samples using standard methods. Sodium and potassium in plasma and urine were determined by standard flame spectrophotometric techniques. $\nmid$ Total calcium and magnesium concentrations in plasma and urine were measured by emission and atomic absorption spectrophotometry ${ }^{3,4}$ respectively. Calcium ion activity was determined on thawed frozen plasma by the method of Radde, et al. ${ }^{5}$

\footnotetext{
"Bentley Sales Inc., 180 Main St., Norwalk, Conn. 06851, U.S.A.
}

fIL Flame spectophotometer, model 143. 


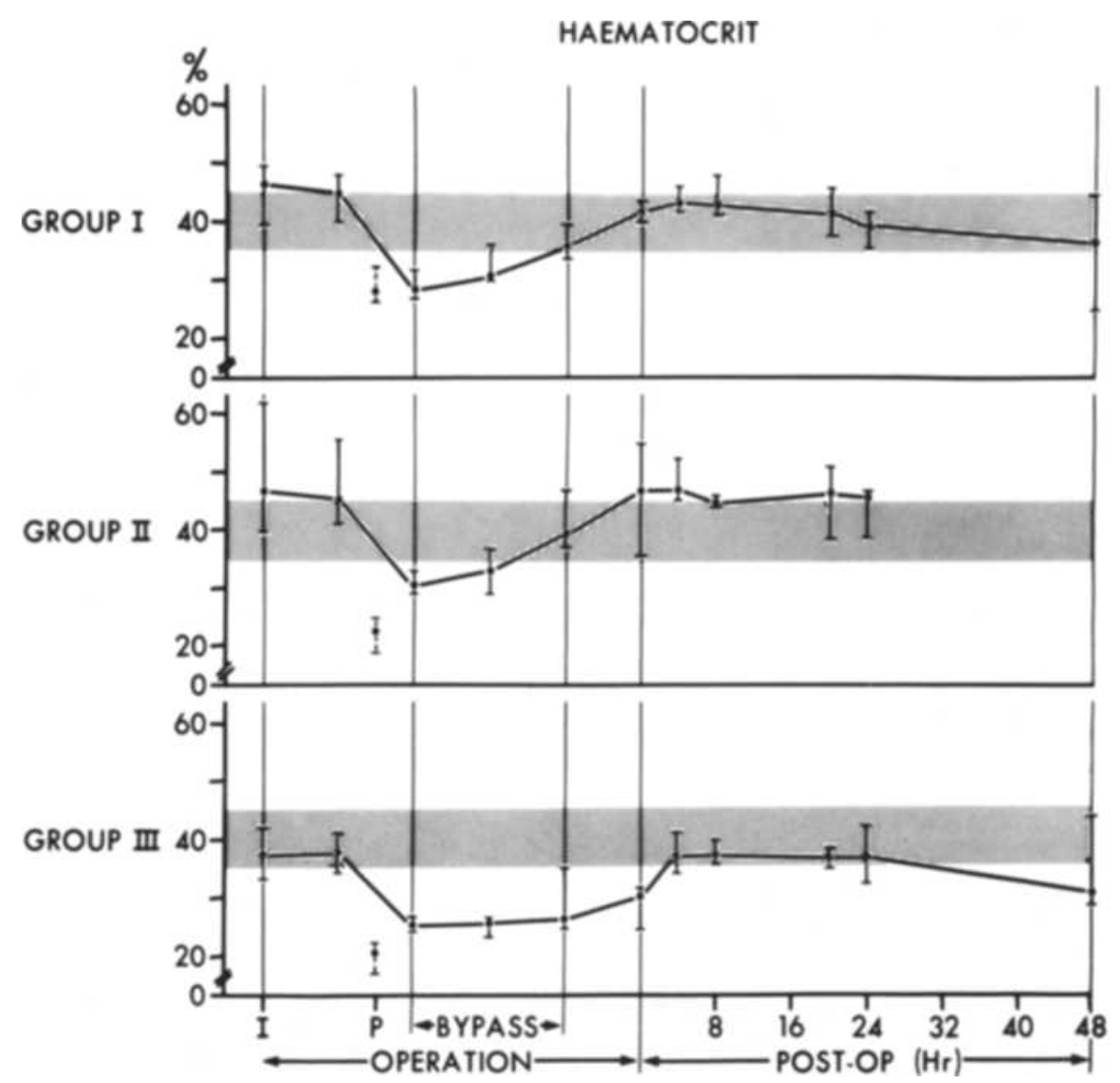

FIgURE 1. Haematocrit, per cent (median \pm range). Shaded areas indicate the normal range. $\mathrm{I}=$ specimen taken at induction; $\mathrm{P}=$ specimen taken from the priming fluid.

Blood sugar concentrations were measured by standard techniques ${ }^{6,7}$ and plasma osmolality by osmometer."

Post-operative fluid management was standardized in all patients with administration of 5 per cent dextrose in 0.2 per cent $\mathrm{NaCl}$ at a rate to give approximately half the calculated normal maintenance volume. In addition, all measured blood losses were replaced with fresh ACD blood.

\section{RESULTS}

\section{Haematocrit}

The haematocrits at induction of anaesthesia and in the pre-bypass specimens were higher in patients with tetralogy of Fallot (Groups I and II) than in patients with ASD (Group III) (Figure 1). In the priming fluids the haematocrits were consistently low in all groups and early in the bypass ranged between 25 and 30 per cent, the desired levels. During bypass and chest closure, the haematocrits

*Model 3-L Osmometer, Advanced Instruments, Inc., Newton Highlands, Mass, 02161, U.S.A. 
TABLE II

Amount of Blood Administered to Patients (ML/KG) $\left(\right.$ Mean $\left.\pm \mathrm{SE}_{\mathrm{m}}\right)$

\begin{tabular}{rrrrr}
\hline Group & Pre-bypass & During Bypass & Post-Bypass & $\begin{array}{r}\text { Postoperatively } \\
\text { (first 24 hours) }\end{array}$ \\
\hline I & $12.9 \pm 1.6$ & $40.6 \pm 6.8$ & $28.5 \pm 6.7$ & $10.8 \pm 3.8$ \\
II & $16.5 \pm 2.8$ & $68.3 \pm 21.4$ & $39.2 \pm 8.5$ & $15.2 \pm 7.0$ \\
III & $10.2 \pm 2.6$ & $6.9 \pm 3.1$ & $11.3 \pm 2.4$ & $7.5 \pm 2.7$ \\
\hline
\end{tabular}

gradually approached pre-bypass values. Post-operatively, haematocrits remained unchanged at first, but tended to decrease on the second day. Table II shows the amount of blood administered to the patients in each group. During bypass the blood was added to the pump directly and at other times it was given intravenously. The marked differences between long-pump-run and short-pump-run cases are obvious.

\section{Arterial $p H$}

At induction, the $\mathrm{pH}$ was elevated in patients of Group III, whereas it was normal in patients of the other two groups (Figure 2). The priming fluids of patients in Group I showed lower $\mathrm{pH}$ values than those of the other two groups. Despite this, patients in Group I became alkalotic during the late stages of bypass and chest closure. Their $\mathrm{pH}$ returned to normal in the early post-operative period, but the patients became alkalotic once more during the second post-operative day. Alkalosis developed in Group II patients late in the first post-operative day and continued, although less severe, during the second post-operative day. Patients in Group III remained in relatively normal acid-base balance throughout operation and the first post-operative day, but their $\mathrm{pH}$ rose also during the second post-operative day.

\section{Plasma Sodium}

Normal plasma sodium concentrations were observed in the induction and prebypass specimens in most patients (Figure 3 ). The priming solutions showed a marked difference: those of Groups I and III contained sodium in physiological concentrations $(135 \mathrm{mEq} / \mathrm{L})$, whilst those of Group II were lower $(75 \mathrm{mEq} / \mathrm{L})$. In the early bypass specimens plasma $\mathrm{Na}^{+}$decreased slightly from pre-bypass values with little difference between Groups I and III. In contrast, in patients of Group II, plasma $\mathrm{Na}^{+}$decreased rapidly and markedly in the early bypass samples. This severe hyponatraemia in Group II continued throughout the period of bypass and all the patients in the group were still hyponatraemic during chest closure. Normal $\mathrm{Na}^{+}$values were not reached until 4 hours post-operatively. In Group I, most patients had normal plasma sodium concentrations during chest closure and in the early post-operative period. Patients of Group III remained slightly hyponatraemic during bypass and chest closure but normal values were observed 4 hours post-operatively. During the second 24 post-operative hours all patients in the three groups became hyponatraemic. 


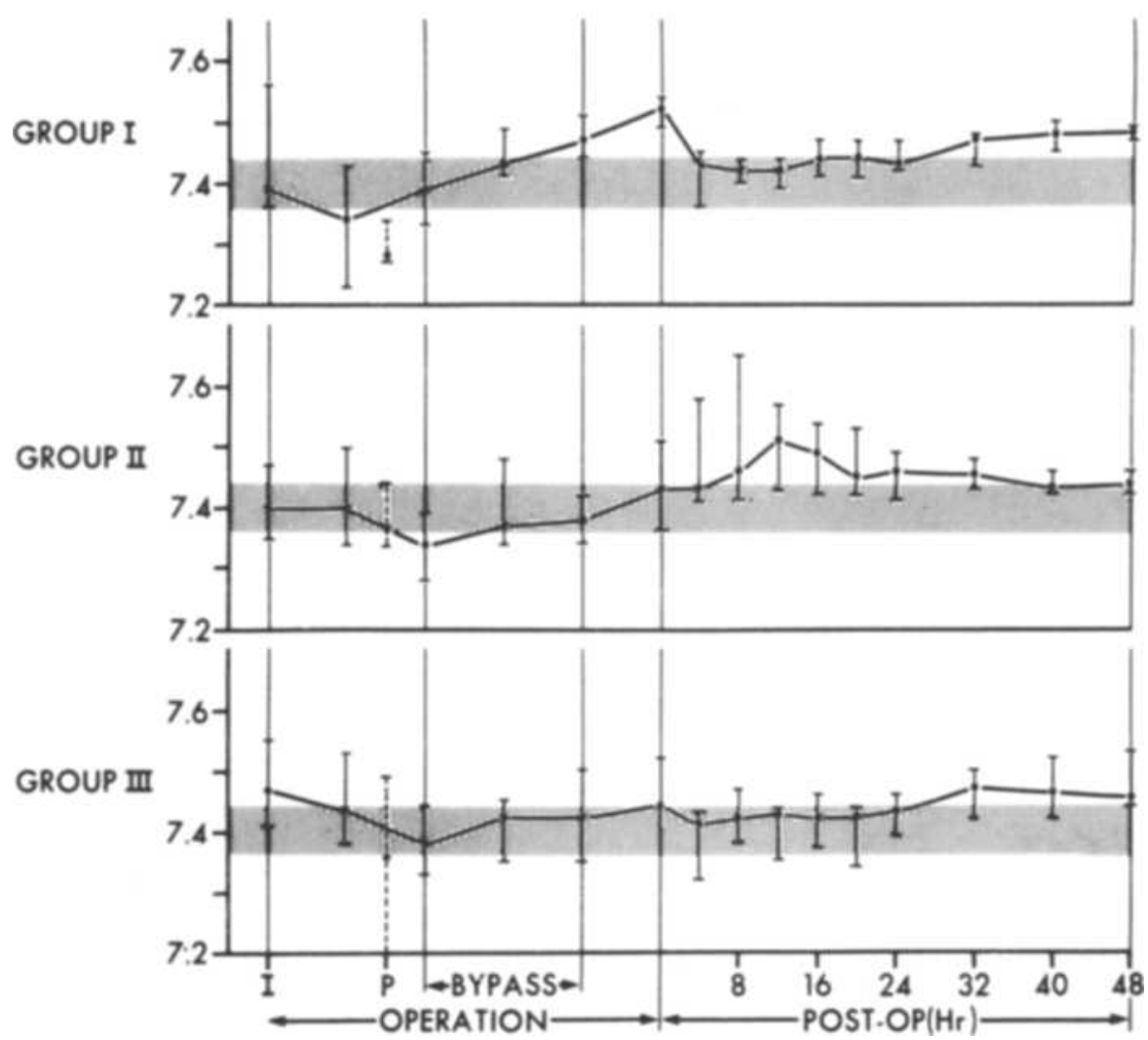

FIGURE 2. Arterial blood $\mathrm{pH}$ (median \pm range). Shaded areas indicate the normal range. $\mathrm{I}=$ specimen taken at induction; $P=$ specimen taken from the priming fluid.

\section{Plasma Potassium}

Plasma potassium values showed very little difference between the three groups (Figure 4). Potassium values were elevated in the priming fluids used in Groups I and III, and subnormal in those of Group II. In spite of these differences in the priming fluids, plasma potassium concentrations during bypass did not differ between Groups I and II, gradually decreasing in value. Steady levels of plasma potassium were maintained in the short-pump-run patients (Group III) throughout operation. Post-operatively, patients in Groups I and II were hypokalaemic, and those in Group III less so or normokalaemic. None of the patients received post-operative potassium therapy.

\section{Total Plasma Magnesium}

The pattern of change in plasma magnesium was similar in Groups I and III; most values remained within normal limits throughout operation, and decreased post-operatively to levels below or just at the lower limit of normal (Figure 5). The concentration of magnesium in the priming fluids used in Group II was sig- 


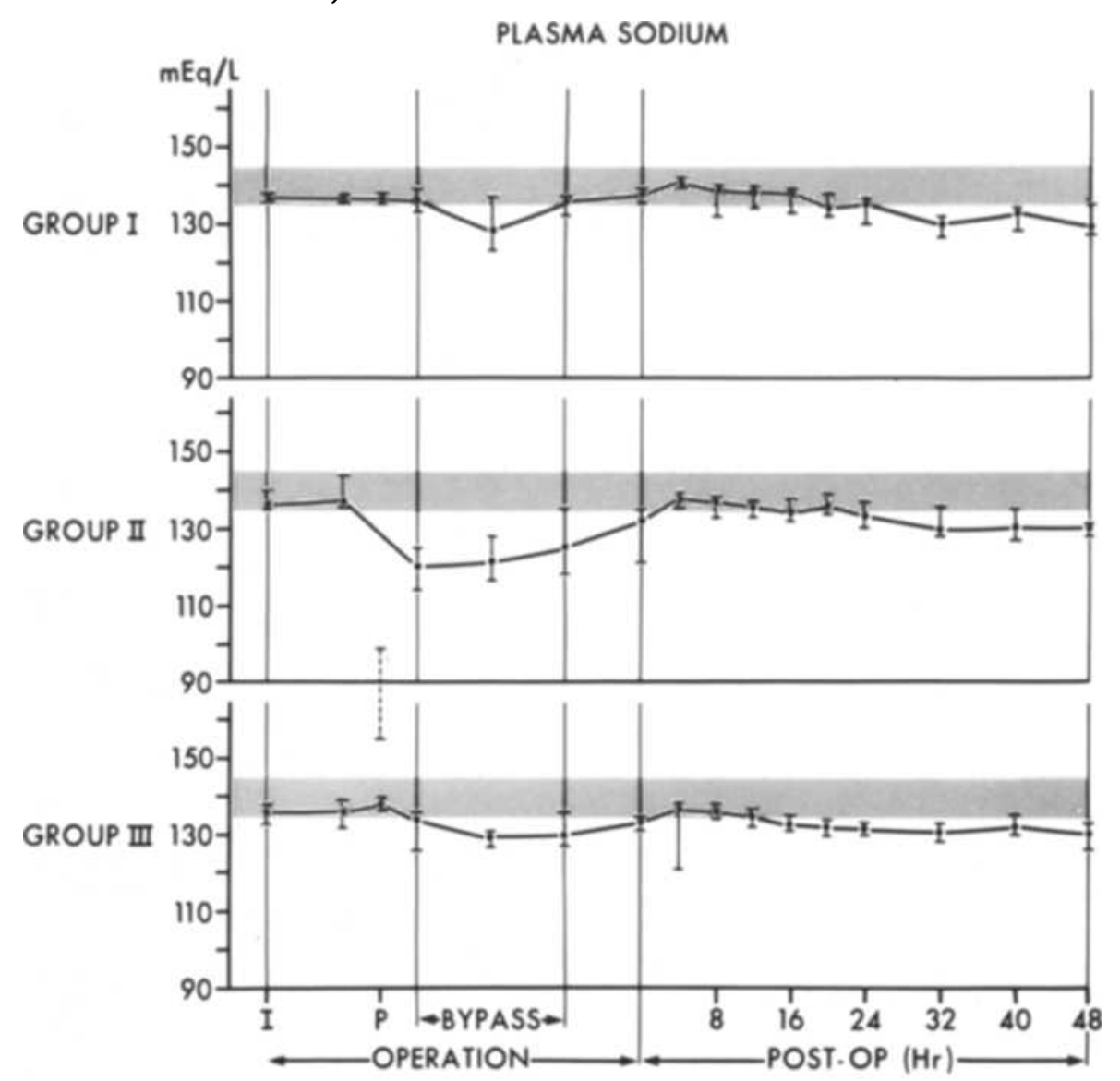

FIGURE 3. Plasma sodium concentration, $\mathrm{mEq} /$ litre (median ${ }^{ \pm}$range). Shaded areas indicate the normal range. $\mathrm{I}=$ specimen taken at induction; $\mathrm{P}=$ specimen taken from priming fluid.

nificantly lower than that in the other two groups. This resulted in depressed magnesium levels in Group II patients at the start of bypass. However, there was a gradual rise in plasma magnesium during bypass and the values remained at the lower limit of normal during the post-operative period. No significant differences in intra-operative magnesium levels in plasma were seen between longpump-run and short-pump-run patients.

\section{Plasma Calcium}

(a) Total Calcium. Total calcium in the priming fluids of all three groups was high, with medians between 11 and $13 \mathrm{mEq} / \mathrm{L}$ (Figure 6). The pattern for Groups I and II was the same. The normal values observed at induction of anaesthesia were followed by an increase in plasma total calcium at the start of bypass. The level remained elevated throughout operation, with values returning to normal by the end of the fourth post-operative hour. Values around the lower limit of normal were then present for the remaining observation period. Group II also demonstrated the same changes during operation, but the patients remained hyper- 


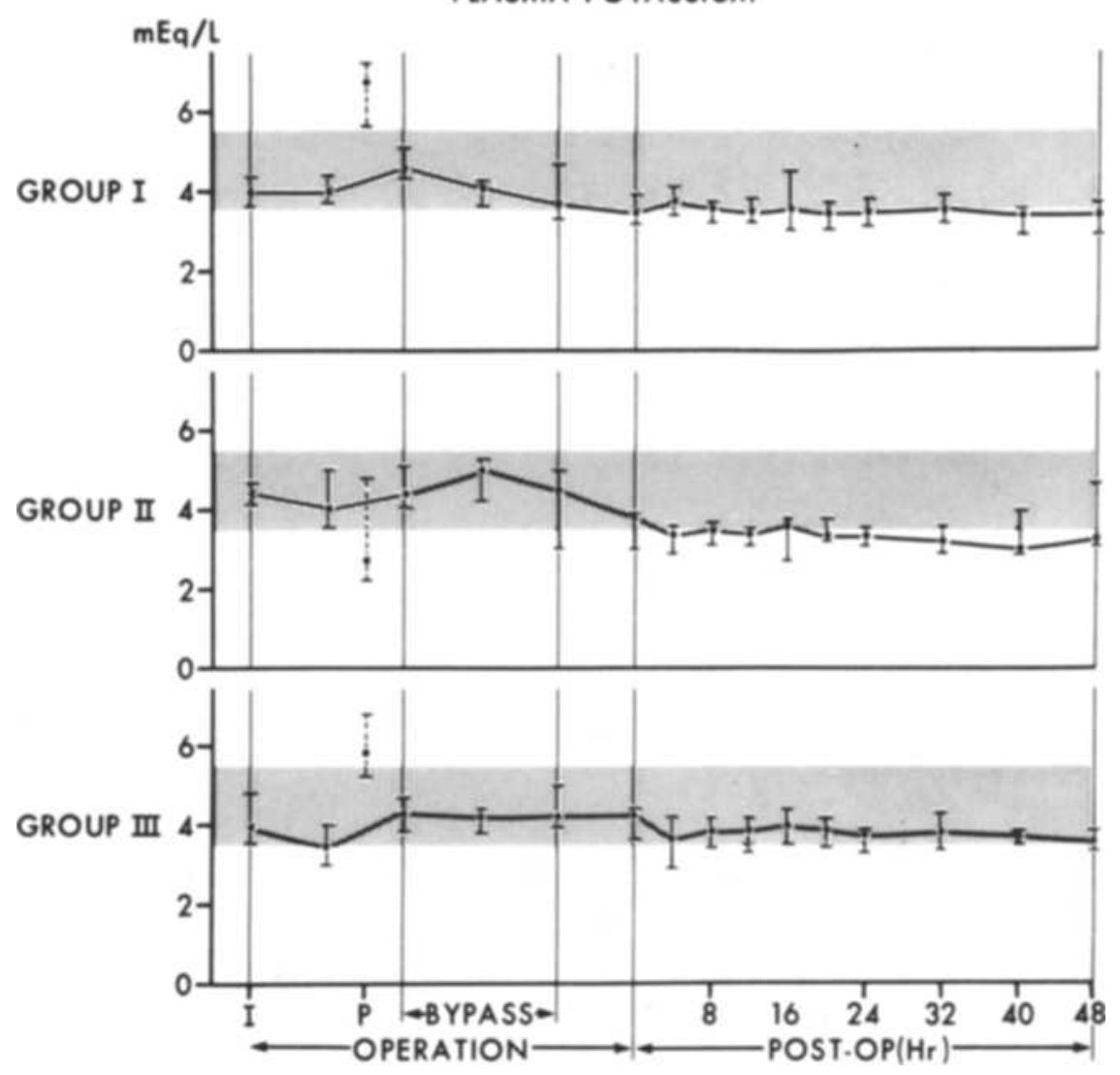

Figure 4. Plasma potassium concentration, $\mathrm{mEq} /$ litre (median \pm range). Shaded areas indicate the normal range. $\mathrm{I}=$ specimen taken at induction; $\mathrm{P}=$ specimen taken from the priming fluid.

calcaemic for the first 8 post-operative hours, and their values became slightly subnormal by the end of the first post-operative day.

(b) Ionized Calcium. Calcium ion activity in the priming fluids of all three groups was low (Figure 7). Groups I and II showed the same pattern of changes during operation and the early post-operative period. The initially normal values decreased to the lower limit of normal at the start of bypass, then rose to hypercalcaemic levels during bypass, and decreased again during chest closure, with values remaining above the normal range. By the fourth post-operative hour, calcium ion activity had returned to normal in both groups. In the later postoperative period, ionic calcium in Group I remained at the lower limit of normal, whereas patients of Group II became hypocalcaemic (ionized fraction). Plasma calcium values in Group III remained within normal limits throughout the period of observation, with the exception of the early bypass specimen which had slightly subnormal values.

\section{Plasma Protein Concentrations}

All patients exhibited a fall in plasma protein levels when bypass was started. This fall persisted until chest closure in Group I and III, but not in Group II 


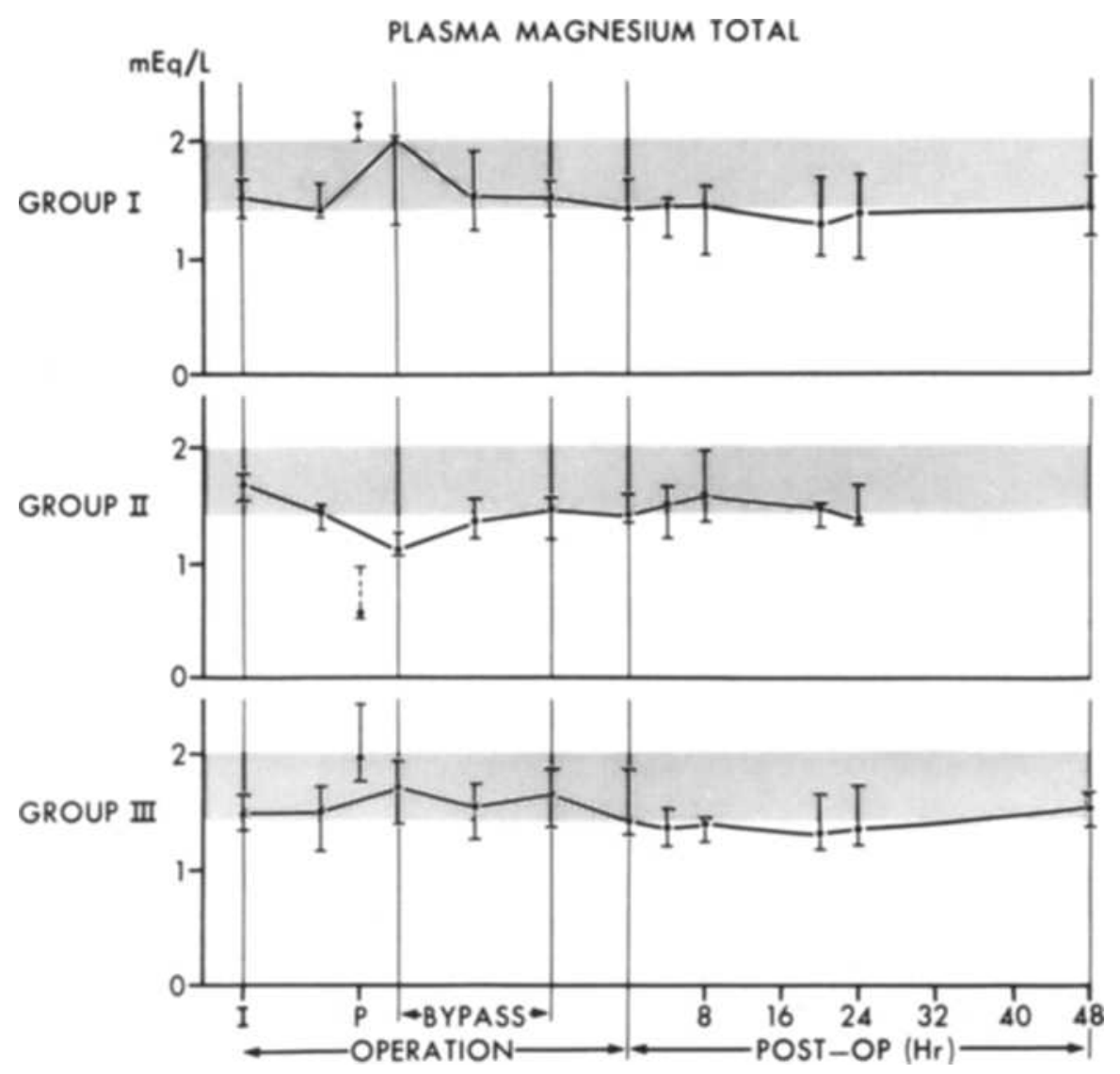

Figure 5. Total plasma magnesium concentration, $\mathrm{mEq} /$ litre (median \pm range). Shaded areas indicate the normal range. $I=$ specimen taken at induction; $P=$ specimen taken from the priming fluid.

(Figure 8). Values in Group II remained within normal limits during the postoperative period, whereas those in Group I and III remained at the lower limit or just below normal.

\section{Plasma Osmolality and Blood Sugar}

The addition of 1 per cent dextrose to Plasma-lyte in the primes of Groups I and III increased the glucose concentrations to an average of $750 \mathrm{mg}$ per $100 \mathrm{ml}$. During perfusion and chest closure they ranged around $300 \mathrm{mg}$ per $100 \mathrm{ml}$. The majority of values at the 24th post-operative hour were only slightly elevated.

The values for plasma osmolality in Groups I and III reflected the blood sugar changes, being $350 \mathrm{mOsm} / \mathrm{kg}$ on the average in the primes and between 300 and $315 \mathrm{~m} \mathrm{Osm} / \mathrm{kg}$ during bypass. Post-operatively, a rapid decrease to normal or low normal levels was observed.

\section{Urinary Excretion}

(a) Urinary Volume and Flow Rate. Urinary output, expressed as a proportion of diluent added to the priming fluid, differed between the long-pump-run and the 


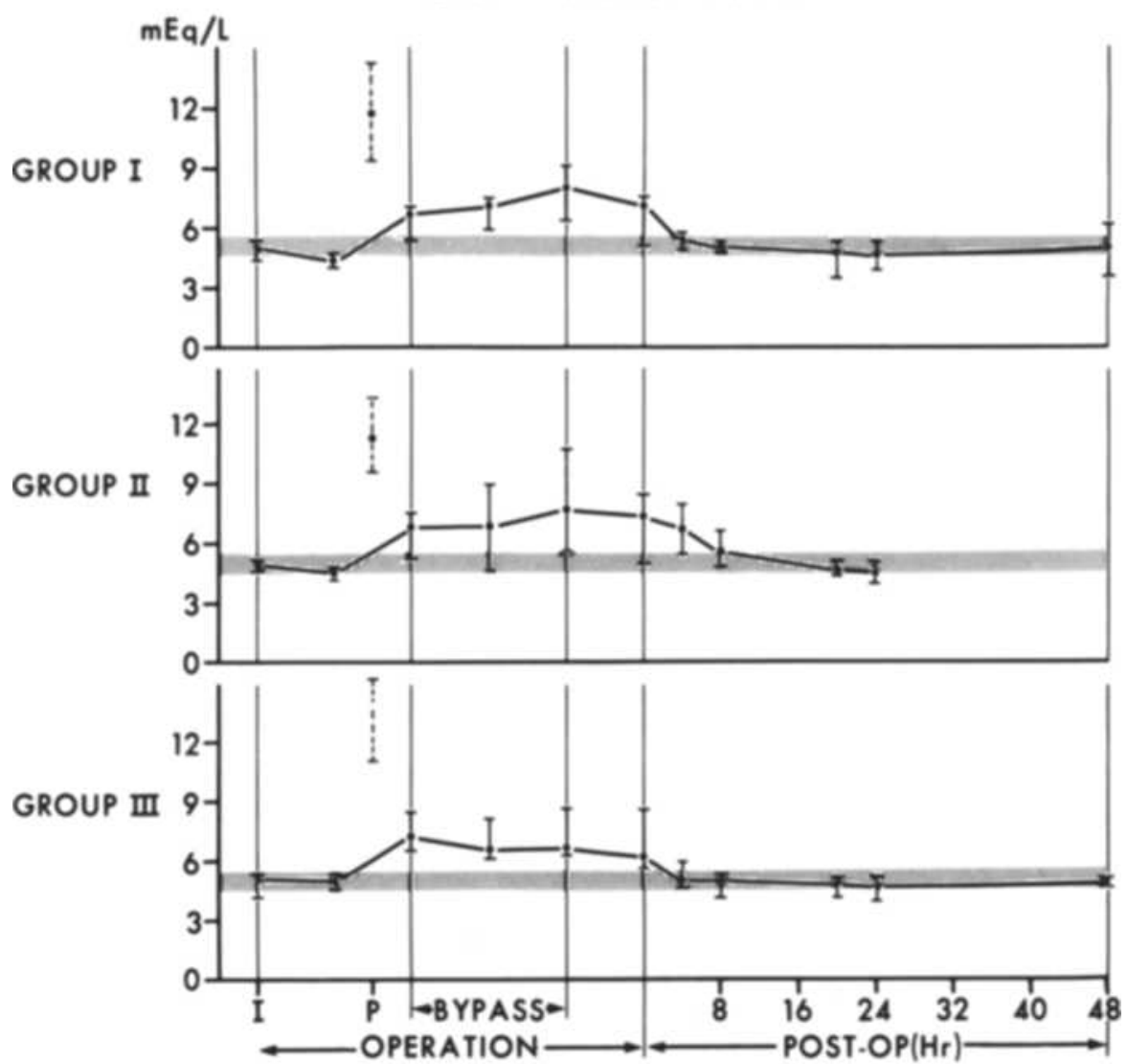

Figure 6. Total plasma calcium concentration, $\mathrm{mEq} /$ litre (median \pm range). Shaded areas indicate the nornal range. $\mathrm{I}=$ specimen taken at induction; specimen taken from the priming fluid.

short-pump-run cases (Table III). Whereas by the end of the four post-operative hours, the urine volume in Groups I and II exceeded or was equal to that of the diluent in the priming fluid, the patients of Group III, because of the shorter duration of bypass, had excreted only a volume equivalent to 70 per cent.

Between start of bypass and the end of the fourth post-operative hour all patients showed high flow rates $(\mathrm{ml} / \mathrm{kg} / \mathrm{hr}$ ). However, in Group I the flow rate from start of bypass to the end of the first post-operative day was higher than in Groups II and III. Flow rates were normal in all groups after the first 4 hours but higher in Group III during the second post-operative day than in the other two groups.

(b) Electrolyte Excretion (Table IV). Urinary sodium excretion in absolute amounts $(\mathrm{mEq} / \mathrm{kg})$ was higher in patients of Group I than in patients of Group II during the period from start of bypass until the end of the fourth post-operative hour. The amount of sodium excreted during the operation and until the end of the first day was higher in the patients whose prime contained Plasma-lyte 

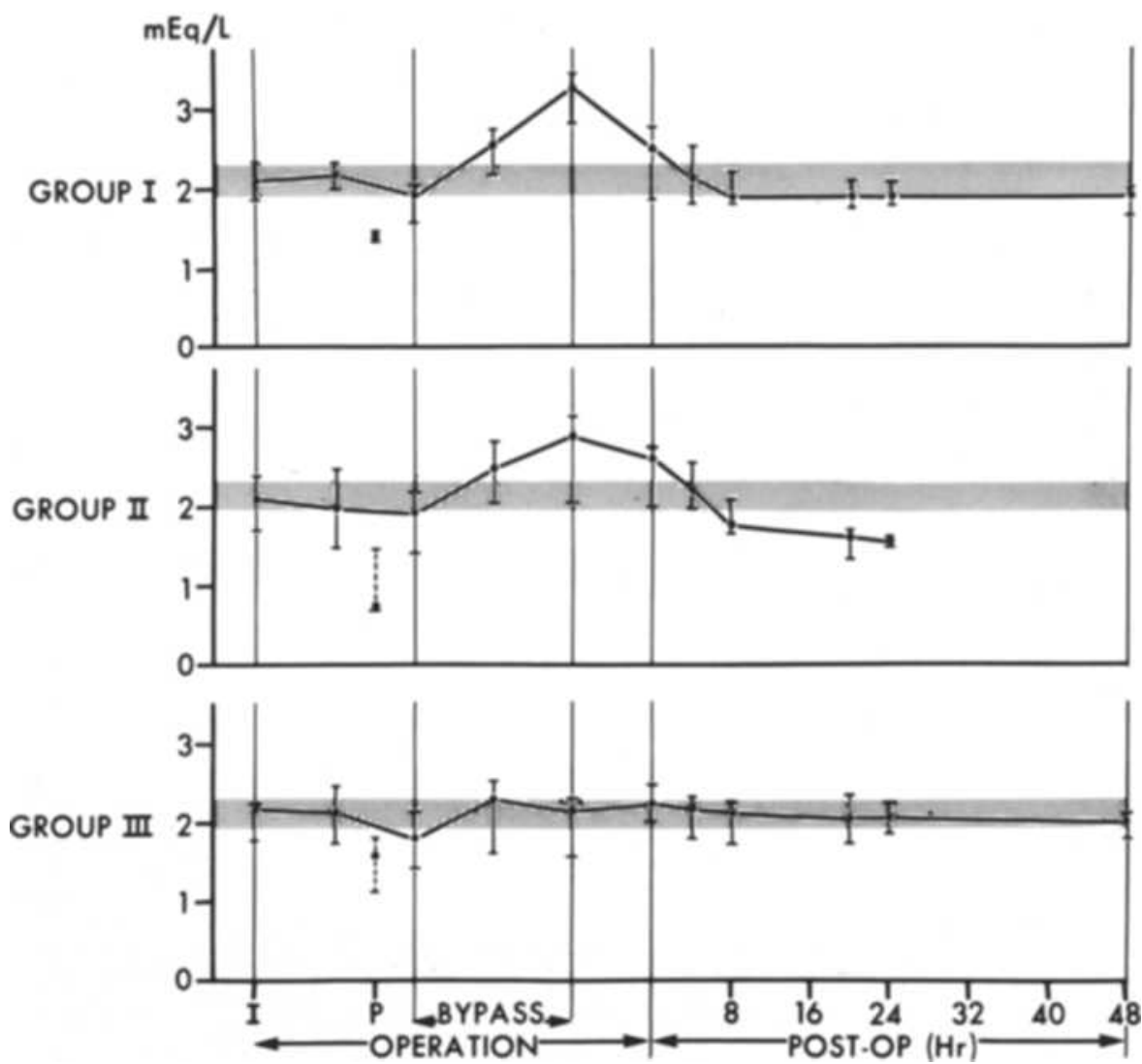

Figure 7. Plasma calcium activity, $\mathrm{mEq} /$ litre (median \pm range). Shaded areas indicate the normal range. $I=$ specimen taken at induction; $P=$ specimen taken from the priming fluid.

TABLE III

URINARY OUTPUT (Mean $\pm \mathrm{SE}_{\mathrm{m}}$ )

\begin{tabular}{|c|c|c|c|c|c|}
\hline \multirow[b]{2}{*}{ Group } & \multicolumn{2}{|c|}{$\begin{array}{c}\text { As proportion of diluent added to } \\
\text { priming fluid }\end{array}$} & \multicolumn{3}{|c|}{$\begin{array}{l}\text { As Flow Rate } \\
(\mathrm{ml} / \mathrm{kg} / \mathrm{hr})\end{array}$} \\
\hline & $\begin{array}{c}\text { Start of Bypass } \\
\text { until end of } \\
\text { operation }\end{array}$ & $\begin{array}{l}\text { Start of Bypass } \\
\text { until end of } 4 \text { th } \\
\text { postoperative } \\
\text { hour }\end{array}$ & $\begin{array}{c}\text { Start of Bypass } \\
\text { until end of } 4 \text { th } \\
\text { postoperative } \\
\text { hour }\end{array}$ & $\begin{array}{l}4 \text { to } 24 \text { hours } \\
\text { postoperatively }\end{array}$ & $\begin{array}{c}24 \text { to } 48 \text { hours } \\
\text { post- } \\
\text { operatively }\end{array}$ \\
\hline $\begin{array}{r}\text { I } \\
\text { II } \\
\text { III }\end{array}$ & $\begin{array}{l}0.89 \pm 0.18 \\
0.80 \pm 0.10 \\
0.39 \pm 0.05\end{array}$ & $\begin{array}{l}1.20 \pm 0.15 \\
1.03 \pm 0.09 \\
0.71 \pm 0.11\end{array}$ & $\begin{array}{l}6.96 \pm 0.94 \\
5.32 \pm 0.55 \\
4.86 \pm 0.71\end{array}$ & $\begin{array}{l}1.05 \pm 0.14 \\
0.84 \pm 0.06 \\
1.14 \pm 0.21\end{array}$ & $\begin{array}{l}1.54 \pm 0.36 \\
1.58 \pm 0.31 \\
2.04 \pm 0.19\end{array}$ \\
\hline
\end{tabular}

(Groups I and III) than in those whose prime did not (Group II). During the second post-operative day sodium excretion did not differ between the groups.

Potassium excretion was similar for all groups from the start of bypass until the end of the fourth post-operative hour. After this time potassium excretion became greater in patients of Groups I and III than in those of Group II. 


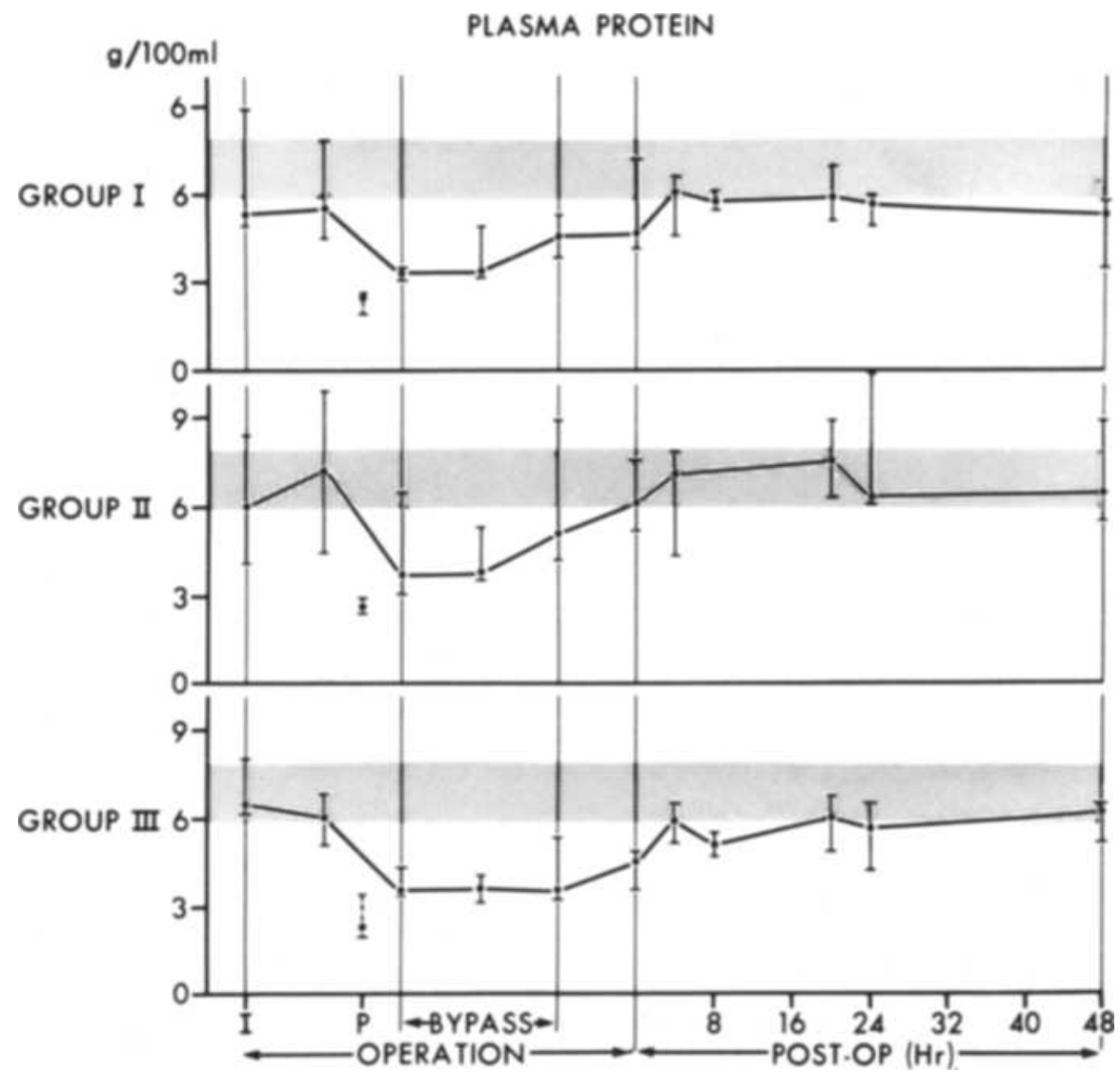

Figure 8. Plasma total protein concentration, gm/100 ml (median \pm range). Shaded areas indicate the normal range. $\mathrm{I}=$ specimen taken at induction; $\mathrm{P}=$ specimen taken from the priming fluid.

TABLE IV

Cation Excretion in Urine (mEq/kg)

$\left(\right.$ Mean $\left.\pm \mathrm{SE}_{\mathrm{m}}\right)$

\begin{tabular}{|c|c|c|c|c|}
\hline & Group & $\begin{array}{l}\text { Start of bypass } \\
\text { to } 4 \text { hours } \\
\text { postoperatively }\end{array}$ & $\begin{array}{l}4 \text { to } 24 \text { hours } \\
\text { postoperatively }\end{array}$ & $\begin{array}{l}24 \text { to } 48 \text { hours } \\
\text { postoperatively }\end{array}$ \\
\hline \multirow[t]{2}{*}{ Sodium } & I & $2.56 \pm 0.67$ & $1.78 \pm 0.51$ & $1.19 \pm 0.46$ \\
\hline & II & $1.200 \pm 0.29$ & $\begin{array}{l}1.08 \pm 0.43 \\
2.21+0.48\end{array}$ & $\begin{array}{l}1.69 \pm 0.69 \\
1.34+0.47\end{array}$ \\
\hline \multirow[t]{3}{*}{ Potassium } & I & $1.19 \pm 0.15$ & $1.75 \pm 0.24$ & $1.33 \pm 0.20$ \\
\hline & II & $1.03 \pm 0.17$ & $1.51 \pm 0.25$ & $0.86 \pm 0.10$ \\
\hline & III & $0.85 \pm 0.18$ & $2.08 \pm 0.16$ & $1.24 \pm 0.15$ \\
\hline \multirow{3}{*}{ Calcium } & I & $0.39 \pm 0.06$ & $0.05 \pm 0.00$ & $0.05 \pm 0.00$ \\
\hline & II & $0.31 \pm 0.17$ & $0.16 \pm 0.03$ & $0.02 \pm 0.01$ \\
\hline & III & $0.20 \pm 0.06$ & $0.06 \pm 0.02$ & $0.20 \pm 0.04$ \\
\hline \multirow{3}{*}{ Magnesium } & I & $0.18 \pm 0.02$ & $0.01 \pm 0.02$ & $0.23 \pm 0.04$ \\
\hline & II & $0.07 \pm 0.01$ & $0.07 \pm 0.03$ & $0.01 \pm 0.04$ \\
\hline & III & $0.13 \pm 0.02$ & $0.16 \pm 0.03$ & $0.31 \pm 0.04$ \\
\hline
\end{tabular}


(c) Calcium and Magnesium Excretion. No significant differences in calcium excretion were found at any time between the three patient groups.

Magnesium excretion was significantly higher in patients receiving Plasma-lyte as the prime diluent (Groups I and III) than in patients whose diluent was 5 per cent dextrose in 0.2 per cent $\mathrm{NaCl}$ (Group II).

\section{Discussion}

Our purpose in this study was twofold: (1) to minimize intra- and post-operative biochemical abnormalities occurring in children undergoing open heart surgery by using a more "physiological" combination of ions in the priming fluid than had been customary previously, and (2) to determine whether the duration of bypass has any significant influence on the development of these abnormalities. We have been only partially successful in our first objective since the post-operative abnormalities remained essentially unaltered.

Plasma-lyte was chosen as the physiological diluent for comparison with the customary 5 per cent dextrose in 0.2 per cent $\mathrm{NaCl}$ as it contains magnesium ( $3 \mathrm{mEq} /$ litre), whereas many other physiological solutions such as lactated Ringer's solution contain none. The addition of this relatively small amount of magnesium in the priming fluid had a beneficial effect during bypass as the patients receiving the Plasma-lyte in the priming solution remained normomagnesaemic during operation and those receiving the 5 per cent dextrose in 0.2 per cent $\mathrm{NaCl}$ became hypomagnesaemic. However, this benefit did not extend into the postoperative period when the majority of patients in Groups I and III became mildly to moderately hypomagnesaemic. This may have been due to the prompt urinary excretion of magnesium in the magnesium-supplemented groups.

The degree of intra-operative hypomagnesaemia is probably greater than is apjarent from our data as we measured only total magnesium concentrations in the Jlasma, whereas it is the ionic fraction which is of physiological importance. Resently, an attempt has been made to calculate ionic magnesium levels during and :ollowing bypass ${ }^{8}$ but the values cannot be verified at present by direct measurenent. Calculation of ionized magnesium concentrations in our patients using this nethod produced results similar to those reported by Killen and his associates, but he values differ considerably from those obtained by measuring ultra-filterable nagnesium concentrations. ${ }^{9}$ Furthermore, normal values calculated in this manner liffer significantly from normal values obtained by direct measurement. ${ }^{10,11}$ We uspect that direct measurement of ionic magnesium under anaerobic conditions vill give more meaninguful results. Probably much more magnesium will have to re added to the priming solution than is sufficient to bring total magnesium levels ip to normal values, and only then will normal ionic magnesium concentrations be raintained during bypass.

Because of the central role of magnesium ions in energy metabolism and our ndings of post-operative hypomagnesaemia we advocate post-operative supplerentation with magnesium ( $1 \mathrm{mEq} / \mathrm{kg} /$ day intravenously or intramuscularly).

The second plasma constituent which we attempted to influence during bypass ras sodium. The twofold increase in sodium concentration of the Plasma-lyte 
priming solution over that of the 5 per cent dextrose in 0.2 per cent $\mathrm{NaCl}$, largely prevented the severe hyponatraemia during bypass. However, it did not influence either the development or the degree of post-operative hyponatraemia, which was particularly conspicuous on the second post-operative day. The increase in sodium load led to increased natriuresis in Plasma-lyte-treated patients, but no differences were seen between long- and short-pump-run cases. It has been shown previously ${ }^{2}$ that the hyponatraemia occurring on the first post-operative day can be prevented by administering sufficient potassium to restore normal plasma potassium levels. We also suspect that the late post-operative hyponatraemia occurs partially on the basis of electrolyte shifts and may well be due to diminished glomerular filtration rate and water retention during this period.

Intra-operative potassium changes differed only slightly between groups and showed little relationship with potassium concentrations in the diluent. Furthermore, the use of potassium in the priming fluid at the concentrations present in Plasma-lyte $(5 \mathrm{mEq} /$ litre) did not prevent post-operative hypokalaemia. In view of this, plus the previously published report on the action of post-operative potassium supplements on plasma sodium levels, ${ }^{2}$ it seems wise to administer such supplements to all paediatric patients undergoing cardiopulmonary bypass with haemodilution and a perfusion exceeding 30 minutes in time.

An interesting phenomenon noted on examination of the results for plasma sodium and potassium at the time of institution of bypass was that all patients in Group II had an increase in plasma potassium, despite the low concentrations of potassium in the priming solution, and that this was associated with decreased $\mathrm{pH}$. Conversely, many patients of Groups I and III showed decreases in plasma sodium at that time, despite the normal or high concentrations of sodium in the priming fluids. Both these effects are exactly opposite to purely dilutional effects. Thus, many of the changes that occur at this time must be due to intercompartmental shifts of fluid and electrolytes, probably related to $\mathrm{pH}$ and osmolality, rather than to simple dilutional effects.

The alkalosis shown by patients in Group I during late bypass and operation may be partially due to the substantial amounts $(50 \mathrm{mEq} /$ litre $)$ of potential bicarbonate as acetate and gluconate contained in Plasma-lyte, as well as to delayed metabolism of citrate in the ACD blood. ${ }^{12,13}$ The tendency to alkalosis shown by all patients at some time during the post-operative period may contribute to post-operative hypokalaemia and vice versa.

During operation and post-operatively, short-pump-run patients received less blood than patients in the other two groups and they were able to maintain plasma potassium largely within normal limits. The post-operative differences in plasma potassium between patients of Groups I and III were not due to differences in urinary excretion. The large amounts of dextrose in the large volumes of acidcitrate-dextrose blood given to the long-pump-run patients may play some role in hormonal secretion and subsequent transfer of cations $\left(\mathrm{K}^{+}\right.$and $\left.\mathrm{Mg}^{++}\right)$into the cells, ${ }^{14-16}$ but the exact role remains to be clarified.

Duration of bypass also influenced haematocrit and plasma sodium differences between long-pump-run and short-pump-run cases but these changes seem to be related to the fact that during the short time on bypass full stabilization did not occur, as it did with the longer runs. 
We have no explanation for the post-operative differences in haematocrit and plasma protein values between Groups I and II. However, during bypass the degree of hypoproteinaemia was similar in all groups, confirming the equal and successful haemodilution.

\section{Conclustons}

The use of a multiple electrolyte solution containing physiological cation concentrations (such as Plasma-lyte ${ }^{\circledR}$ ) as the diluent in the pump oxygenator priming fluid, is of value in maintaining plasma electrolyte values close to normal during bypass. However, Plasma-lyte does not appear to have much beneficial effect in the post-operative period. Thus, we recommend:

(1) the use of multiple electrolyte solution for haemodilution;

(2) the routine administration of magnesium supplements post-operatively in a dosage of $1 \mathrm{mEq} / \mathrm{kg} /$ day; and

(3) the routine administration of potassium post-operatively if bypass time exceeds 30 minutes, in a dosage of $2 \mathrm{mEq} / \mathrm{kg}$ per 24 hours for at least 48 hours.

In this way we would hope that the incidence and severity of post-operative alkalosis, hypomagnesaemia, hypokalaemia, and hyponatraemia are minimized.

\section{SUMMARY}

The material presented in this paper is part of an ongoing project to study biochemical changes in children undergoing 30 per cent haemodilution during cardiopulmonary bypass for open heart operations.

We compared two groups of 5 children undergoing total correction of tetralogy of Fallot and having cardiac bypass times over 50 minutes: the diluent used in Group I was magnesium-containing Plasma-lyte ${ }^{\left({ }^{*}\right.}$ with dextrose added to make a 1 per cent solution, while that in Group II was 5 per cent dextrose in 0.2 per cent $\mathrm{NaCl}$. The results indicate that the use of magnesium-containing multiple electrolyte solution was of value in maintaining plasma electrolyte values close to normal during the period of cardio-pulmonary bypass, particularly those of magnesium and sodium, but did not appear to have any appreciable effect on the early post-operative hypokalaemia or late post-operative hyponatraemia.

The patients of Group I were compared with a third group (Group III) of six patients undergoing closure of atrial septal defect with bypass times of less than 30 minutes and using the same multiple electrolyte diluent as in Group I. The short-pump-run cases showed a lower incidence of post-operative hypokalaemia. There were no significant differences in post-operative excretion of sodium or potassium between these two groups (I and III), but there was delayed diuresis until the second post-operative day.

For haemodilution we recommend the use of a magnesium-containing multiple electrolyte solution combined with post-operative administration of magnesium supplement in the amount of $1 \mathrm{mEq} / \mathrm{kg} /$ day and potassium in the amount of 2 $\mathrm{mEq} / \mathrm{kg} /$ day for at least 48 hours. 


\section{RÉSUMÉ}

Ce que nous présentons dans cet article fait partie d'un projet en cours vù nous voulons étudier les changements biochimiques chez les enfants qui, au cours de la chirurgie à coeur ouvert et de la circulation extracorporelle, subissent 30 pour cent d'hémodilution.

Nous comparons deux groupes de cinq enfants soumis à une correction totale de tétrologie de Fallot et ayant eu une durée de circulation extra-corporelle d'audelà de 50 minutes; chez les enfants du premier groupe, le diluant contenait du magnésium, dans de plasma-lyte ${ }^{\circledR}$ et une addition de dextrose pour réaliser une solution à 1 pour cent; chez les enfants du deuxième groupe, le diluant contenait de la dextrose à 5 pour cent et du chlorure de sodium à 0.2 pour cent. Les résultats demontrent que la solution qui contient du magnésium et plusieurs électrolytes réussissait à conserver l'équilibre éléctrolitique du plasma près de la normale au cours de la circulation extracorporelle particulièrement si elle contenait du magnésium et du chlorure de sodium; toutefois, cette solution n'a pas semblé produire un effet appréciable sur l'hypokaliémie post-opératoire précoce ou l'hyponatrémie post-opératoire tardive.

Nous avons comparé les enfants du groupe I avec ceux d'un troisième groupe (gr III) comptant six malades ayant subi une fermeture de communication interauriculaire avec une durée de circulation extra-corporelle de moins de 30 minutes en utilisant le même solution à plusieurs électrolytes employée pour le groupe $\mathbf{I}$. Les cas où la durée de séjour sous la pompe a été courte, ont manifesté un taux inférieur d'hypokaliémie post-opératoire. Dans les suites opératoires, on a constaté peu de différences dans l'excrétion de sodium ou de potassium entre les enfants de ces deux groupes (I et III); toutefois, la diurèse a été retardée au deuxième jour post-opératoire.

Comme diluant nous recommandons une solution contenant du magnésium et de multiples électrolytes et, en période post-opératoire, l'administration additionnelle de magnésium à raison de $1 \mathrm{mEq} / \mathrm{kg} / \mathrm{jour}$ et de potassium à raison de 2 $\mathrm{mEq} / \mathrm{kg} /$ jour durant au moins 48 heures.

\section{ACKNOWLEDGMENTS}

The authors acknowledge with gratitude the co-operation of Dr. William T. Mustard, M.D., F.R.c.s.(c), F.A.c.s., Associate Professor of Surgery, University of Toronto, Chief of Cardiovascular Surgery, The Hospital for Sick Children, Toronto; and Dr. George Trusler, M.D., F.R.c.s.(c), F.A.C.s., Assistant Professor of Surgery, University of Toronto, Cardiovascular Surgeon, The Hospital for Sick Children, for allowing us to carry out these measurements on their patients.

The authors also acknowledge with gratitude the assistance and co-operation of Miss Patricia Morrison, R.N., Assistant O.R. Supervisor in charge of Cardiovascular Surgery and her Nursing Staff; and Mr. Jamie Villemater, R.N., in charge of the Extracorporeal Circulation Unit; and the Nursing Staff in the Intensive Care Unit, The Hospital for Sick Children, Toronto.

This work was supported in part by the Medical Research Council of Canada (Grant \#MA4386). 


\section{REFERENCES}

I. Johnston, A.E., Radde, I.C., Nisbet, H.I.A., \& TAYlor, J. Effects on divalent cations of a haemodilution technique using ACD blood in paediatric patients undergoing bypass open-heart surgery. Canad. Anaesth. Soc. J. 19: 498-516 (1972), No. 5, September.

2. Johnston, A.E., RADDE, I.C., Nisbet, H.I.A., \& TAyLOR, J. Effects of altering calcium in the haemodiluted pump prime on sodium and potassium in children undergoing open heart operations. Canad. Anaesth. Soc. J. 19: 517-528 (1972), No. 5, September.

3. MacIntrae, I. Flame photometry. Adv. Clin. Chem., 4: 1-28 (1961).

4. Alcock, N., MACINTYRE, I., \& RADDE, I. The determination of magnesium in biological fluids and tissues by flame spectrophotometry. J. Clin. Pathol. 13: 506-510 (1960).

5. Radde, I.C., Hoffren, B., Parkinson, D.K., Sheepers, J., \& Luckham, A. Practical aspects of a measurement technique for calcium ion activity in plasma. Clin. Chem. 17: 10021006 (1971).

6. Brown, M.E. Ultra-micro sugar determinations using 2,9-dimethyl-1,10-phenanthroline hydrochloride (Neocuproine). Diabetes, 10:60-62 (1961).

7. Bittwer, D.L. \& Manning, J. Automated neocupronine glucose method: critical factors and normal values. In: Technicon Symposia 1966. Automation in analytical chemistry, Volume 1, Mediad Inc., White Plains, N.Y., 1967, p. 33.

8. Killen, D.A., Grogan, E.L., Gower, R.E., Collins, I.S., \& Collins, H.A. Effects of ACD blood prime on plasma calcium and magnesium. Ann. Thorac. Surg. 13: 371-380 (1972).

9. Munday, K.A. \& MAHY, B.W. Determination of ultrafiltrable calcium and magnesium on small quantities of plasma. Clin. Chim. Acta 10: 144-151 (1964).

10. BajPai, P.C., Sugden, D., STERn, L., \& Denton, R.L. Serum ionic magnesium in exchange transfusion. J. Pediatr. 70: 193-199 (1967).

11. Heaton, F.W. The determination of ionized magnesium in serum and urine. Clin. Chim. Acta 15: 139-144 (1967).

12. Litwin, M.S., SMrth, L.L., \& Moore, F.D. Metabolic alkalosis following massive transfusion. Surgery 45: 805-813 (1959).

13. WEYgand, G.R. \& Roos, A. The effects of citrated blood and hypothermia on acid-base balance during cardiopulmonary bypass. Anesthesiology 36: 268-277 (1972).

14. Mitner, R.D.G., Fekete, M., Assan, R., \& Hodge, J.S. Effect of glucose on plasma glucagon, growth hormone, and insulin in exchange transfusion. Arch. Dis. Child. 47: 179-185 (1972).

15. Moffitt, E.A., Rosevear, J.W., Molnar, G.D., \& McGoon, D.C. The effect of glucoseinsulin-potassium solution on ketosis following cardiac surgery. Anesth. Analg. 50: 291297 (1971). 